\title{
Antioxidant Activity of some Nutraceuticals Based on Romanian Black and Red Fruits Mixed Extracts
}

\author{
Ticuţa Negreanu-Pîrjol \\ Rodica Sîrbu \\ Bogdan-Ştefan Negreanu-Pîrjol \\ "Ovidius" University of Constanţa, Faculty of Pharmacy, 1, University Alley, \\ Campus, Corp B, Constanţa, Romania \\ sirbu_27@yahoo.com
}

Doi:10.5901/ajis.2015.v4n1s2p199

\section{Abstract}

With content rich in polyphenols, carotenoids vitamins, minerals and many other bioactive compounds, fruits extracts from Morus nigra L. - black mulberry (blackberry) from Moraceae family, Cerasus avium (syn. Prunus avium) Moench. - bitter cherry from Rosaceae family, Cornus mas L. - cornelian cherry from Cornaceae family, may be useful as a supplementary treatment and especially in preventing many diseases which arise from action of oxidative stress. The aim of this paper is to obtain selected syrups with an increased antioxidant activity based on a mixture of fluids extracts from Morus nigra L. , Cerasus avium (syn. Prunus avium) Moench. and Cornus mas L. indigenous Romanian fruits. Fluid extracts were obtained using different extraction methods (maceration, reflux) and solvents (ethylic alcohol $40 \%$ and $70 \%$ ). The obtained fluid extracts were mixed in different molar ratio and analysed for their physical-chemical properties, total polyphenols assay (Folin-Ciocalteu assay) and total antioxidative capacity by photochemiluminescence method (ACL, Analytik Jena AG procedure). The selected mixed fluid extracts with greatest content of polyphenols and antioxidant activity were used for syrups obtaining. The new obtained syrups were analysed for their physical-chemical properties (appearance, $\mathrm{pH}$ and relative density), polyphenols content and total antioxidative capacity. Preliminary results emphasize that syrups with highest antioxidant activity correlated with the polyphenols content would represent a possible new stimulating nutraceuticals that could be used in oxidative stress associated to different diseases.

Keywords: nutraceutical, black and red fruits, antioxidant activity

\section{Introduction}

Numerous studies have proven that vegetal compounds originated from plants or fruits possess a high spectrum of biological activity. However, polyphenolic extracts (e. g. flavonoids, anthocyanin, tannins etc. ), despite having excellent in vitro bioactivity, demonstrate less or no in vivo actions due to their improper molecular size, resulting in a poor absorption and bioavailability. Moreover, the efficacy of natural polyphenols depends on preserving the stability, bioactivity and bioavailability of the active compounds. Up to now, the development of pharmaceutical formulations has remained restricted to individual chemical drugs, even the properties obtained by using an optimal mixture of bio-active compounds could be strongly influenced by synergism appeared in the system [1 - 5]. With content rich in vitamins, minerals, polyphenols, carotenoids and many other compounds, extracts from Morus nigra L. , Cerasus avium (syn. Prunus avium) Moench. and Cornus mas L. fruits, may be useful as an adjunct in the treatment and especially in preventing many diseases which arise from action of oxidative stress. Morus nigra L. , Cerasus avium (syn. Prunus avium) Moench. and Cornus mas $L$. fruits, as different vegetable products are often used in folk medicine most due to their content in polyphenolic acids with great antioxidative capacity mainly useful in anti - inflammatory diseases, hypoglycemic activities, tonic action due to their synergistic action [6 -8].

Cerasus avium (Moench. ), bitter cherry, contains a variety of active principles, flavonoids, saponosids, carotenoids, terpinoids, volatils oils, with different farmacological actions - healing, emollient, antiinflamatory, antibacterial. The Cerasus avium fruits contain fibers, water, antocyanins, vitamins (nicotinamide, pantotenic acid, piridoxine, riboflavine, tiamine, small amounts of biotine, folic acid, C, E vitamin, caroten, minerals, oligoelements (zinc copper, manganese, cobalt), fluorine, glucids pectins, proteins, lipids and tannins [9, 10]. Organic acids are represented 
by malic acid, citric acid, clorogenic acid, ferrulic acid, caffeic acid, p-cumaric acid and oxalic acid [10]. Due to its flavonoid, $\mathrm{C}$ and $\mathrm{E}$ vitamins, oligoelements content, known for their antioxidant activity, the raw material expressed as Cerasus avium fruits will be studied to establish its antioxidative capacity and therapeutically potential related to this [9, 11].

Morus nigra (L. ), black mulberry, has been used in popular medicine as an analgesic, diuretic, antitussive, sedative, anxiolytic and hypotensive, in addition to its uses in the treatment of a variety of ailments, including inflammatory disorders. There are many studies involving the chemical composition and evaluation of biological and pharmacological properties of Morus nigra. This genus contains a variety of phenols compounds including flavonoids, and a variety of Diels-Alder adduct compounds. Recent investigations revealed that the fruits and leaves of mulberry plants contained many bioactive components, such as alkaloids, anthocyanins, and isoprenylated flavonoids stilbenes, 2arylbenzopyrans, coumarins, chromones, xanthones [12]. Black mulberry fruits are rich in alkaloid components including 1-deoxynojirimycin, which is known as one of the most potent glycosidase inhibitors that decreases blood sugar levels $[13,14]$.

Cornus mas (L. ), cornelian cherry, present a medium biomass which vary between 5 and $7 \mathrm{~g}$ (depends on varieties), representing a significant source for food industry, because of active principles content, being used in juices production. The fresh fruits consumed in small quantities are recommended because of increased intake of minerals and active principles, tonic and refreshing action; the sugar content vary depending on varieties - the average is between $7,5 \%$ and $14 \%$. If the fruits are consumed in big quantities, may occur some unpleasant adverse digestive, nausea, intestinal fermentation [15 - 18].

The aim of this paper is to obtain selected nutraceuticals type syrups with increased antioxidant activity based on a mixture of fluid extracts from Morus nigra L. , Cerasus avium (syn. Prunus avium) Moench. and Cornus mas L. fresh fruits, indigene species. Fluid extracts were obtained using two extraction methods, maceration and refluxing, in solvents (ethyl alcohol $40 \%$ and $70 \%$ concentrations) [19]. The obtained hidroalcoholic extracts were mixed in different ratio and analysed for their physico-chemical properties, polyphenols assay (Folin-Ciocalteu, HPLC assay) [20, 21] and antioxidative capacity by photochemiluminescence method (ACL, Analytik Jena AG procedure) [22, 23]. The obtained results emphasize that syrups with highest antioxidant activity correlated with the polyphenols content would represent a possible new nutritional supplements used in associated oxidative stress dysfunctions.

\section{Material and Methods}

\subsection{Syrups obtaining and analyzing methods}

For the fluid extracts obtaining were selected the follows raw material: Cornus mas L., cornelian cherry fresh fruits (notate C), Morus nigra L. , black mulberry fresh fruits (notate M), Cerasus avium Moench., bitter cherry fresh fruits (notate C).

The methods used for fluid extracts obtaining were maceration in solvent (fresh vegetal product: ethyl alcohol $40 \%$, respectively fresh vegetal product: ethyl alcohol $70 \%$ in 1: 10 ratio), stir and allow soaking in the dark for 10 days in a constant temperature and stirred periodically and respectively refluxing in ethyl alcohol for $2 \mathrm{~h}$ of fresh vegetal product. After 10 days, the extract was filtered, brought to a concentration of $10 \%$ with a $100 \mathrm{~mL}$ volumetric flask and stored at $4^{\circ} \mathrm{C}$. Fluid vegetal extracts assay were $\mathrm{pH}$, relative density and total phenols compounds by Folin Ciocalteu method. Syrups codification and preparation method based on CMC fluid extracts mixture is presented in Tables I - II:

Table I. Samples codification

\begin{tabular}{|c|l|}
\hline Syrup Code & Content in C: M: C fluid extracts mixture / extract preparation method \\
\hline S1 & C: M: C (1: 1: 1) ratio / maceration in $40 \%$ alcohol \\
\hline S2 & C: M: C $(2,5: 1: 1)$ ratio / maceration in $70 \%$ alcohol \\
\hline S3 & C: M: C $(1: 1: 2,5)$ ratio / reflux in $40 \%$ alcohol \\
\hline S4 & C: M: C $(1: 2,5: 1)$ ratio / reflux in $70 \%$ alcohol \\
\hline S5 & C: M: C $(1: 2,5: 1)$ ratio / maceration in $70 \%$ alcohol \\
\hline
\end{tabular}


Table II. Syrups formula based on CMC fluid extracts (S1 - S5)

\begin{tabular}{|l|c|c|}
\hline Ingredients & Quantities (g) Syrups S1 - S4 & Quantities (g) Syrup S5 \\
\hline Simple syrup 64\% & 55 & - \\
\hline Glycerol & 15 & - \\
\hline Sodium carboxymethylcellulose & - & 0.2 \\
\hline Saccharinummatricum & - & 5 \\
\hline C: M: C fluid extracts (1: $1: 1)$ ratio & 30 & - \\
\hline C: M: C fluid extracts $(2,5: 1: 1)$ ratio & 30 & - \\
\hline C: M: C fluid extracts (1:1:2,5) ratio & 30 & - \\
\hline C: M: C fluid extracts (1:2,5: 1$)$ ratio & 30 & 30 \\
\hline C: M: C fluid extracts (1: $2,5: 1)$ ratio & - & 100 \\
\hline Preservative solution ad. & - & \\
\hline
\end{tabular}

The control tests for syrups based on CMC fluid extracts quality were: appearance, $\mathrm{pH}$, relative density, initial and after 30 days of obtaining.

\subsection{HPLC phenolic compounds assay from syrups based on CMC fluid extracts mixture}

For HPLC analysis, the working solution based on syrups $\mathrm{S} 1-\mathrm{S} 5$, were obtained from $0.5 \mathrm{~g}$ sample diluted with $5 \mathrm{~mL}$ methyl alcohol. For the separation, identification and quantification of phenols compounds an adapted standardized HPLC method for total polyphenols determination described by USP 30-NF25 monograph was used.

Apparatus used: HPLC Agilent 1200 quaternary pump, DAD, thermostat, degassing system, autosampler.

Conditions: C18 type chromatographic column, $250 \mathrm{~mm} 4.6 \mathrm{~mm} ; 5 \mathrm{~mm}$ (Zorbax XDB or equivalent); Mobile phase: solution A - $0.1 \%$ phosphoric acid, solution B - acetonitrile; Gradient elution is presented in Table III; Temperature: $35^{\circ} \mathrm{C}$; Flow rate: $1.5 \mathrm{~mL} / \mathrm{min}$; detection: UV - $310 \mathrm{~nm}$; Injection volume: 20; Analysis time: 22 minutes; Reference substances ( $70 \%$ solution in methanol): E-resveratrol $=37 \mathrm{mg} / \mathrm{mL}, \mathrm{Z}$ - resveratrol $=0.22 \mathrm{mg} / \mathrm{mL}$ (obtained by the solution of transresveratrol from UV radiation $\lambda=254 \mathrm{~nm}$ for $12 \mathrm{~h}$ ) acid, caffeic $=0.36 \mathrm{mg} / \mathrm{mL}$, chlorogenic acid $=0.37 \mathrm{mg} / \mathrm{mL}$, cinnamic acid $=0.58 \mathrm{mg} / \mathrm{mL}$, vanillin $0.42 \mathrm{mg} / \mathrm{mL}=0.39 \mathrm{mg}$ gallic acid $/ \mathrm{mL}$, ferulic acid $=0.50 \mathrm{mg} / \mathrm{mL}$, the reference substances were injected 6 times $(20 \mu \mathrm{L})$.

Table III. HPLC - gradient elution

\begin{tabular}{|c|c|c|c|}
\hline No. & Time, min. & Solution $\mathrm{A}, \%$ & Solution $\mathrm{B}, \%$ \\
\hline & $0-13$ & 90 & 10 \\
\hline & 13 & 78 & 22 \\
\hline & 13 & 78 & 22 \\
\hline & 14 & 60 & 40 \\
\hline & 17 & 60 & 40 \\
\hline & 17,5 & 90 & 10 \\
\hline & 22 & 90 & 10 \\
\hline
\end{tabular}

Retention times corresponding to reference substances are presented in Table IV. To simplify measurements worked their mixture.

Table IV. Retention time for phenolic compounds (reference substances)

\begin{tabular}{|c|c|c|}
\hline No. & Phenolic compound & Retention time \pm SD \\
\hline 1. & gallic acid & $0,990 \pm 0,025$ \\
\hline 2. & 3 -methyl galic acid & $2,606 \pm 0,008$ \\
\hline 3. & chlorogenic acid & $3,501 \pm 0,015$ \\
\hline 4. & caffeic acid & $4,598 \pm 0,036$ \\
\hline 5. & vaniline & $6,919 \pm 0,051$ \\
\hline 6. & p-coumaric acid & $7,187 \pm 0,019$ \\
\hline 7. & ferulic acid & $8,565 \pm 0,058$ \\
\hline 8. & $E$ - resveratrol & $14,467 \pm 0,017$ \\
\hline 9. & ellagic acid & $15,303 \pm 0,027$ \\
\hline 10. & Z - resveratrol & $15,751 \pm 0,058$ \\
\hline 11. & cinammic acid & $15,867 \pm 0,007$ \\
\hline
\end{tabular}


Identification and quantitative determination of the active principles of the test solution was performed by comparing chromatograms of standard mixture and the analyzed solution (Fig. 1).

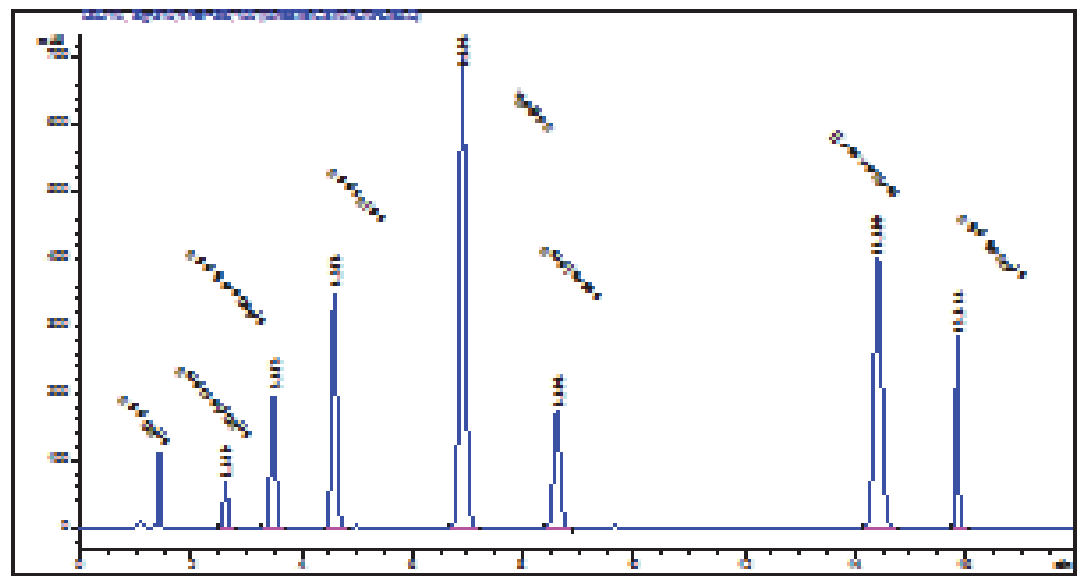

Fig. 1. HPLC chromatogram of the standards mixture

The reproducibility of the method was determined by the square of correlation coefficients (Table V).

Table V. Square of the correlation coefficient of the calibration curves

\begin{tabular}{|c|c|c|}
\hline No. & Phenolic compound & $\mathrm{r}^{2}$ \\
\hline 1. & trans resveratrol & 0.99965 \\
\hline 2. & cis resveratrol & 0.99729 \\
\hline 3. & clhorogenic acid & 0.99999 \\
\hline 4. & caffeic acid & 0.99619 \\
\hline 5. & cinammic acid & 0.99845 \\
\hline 6. & vaniline & 0.99691 \\
\hline 7. & galic acid & 0.99537 \\
\hline 8. & ferulic acid & 0.99863 \\
\hline 9. & ellagic acid & 0.99885 \\
\hline 10. & p - coumaric acid & 0.99798 \\
\hline 11. & 3 - methyl galic acid & 0.99563 \\
\hline
\end{tabular}

\subsection{Antioxidative activity by photochemiluminescence method}

Apparatus used: photochemiluminometer Photochem, Analytik Jena AG, Germany.

Sample preparations for stock solution: $5 \mathrm{~g}$ of syrups $\mathrm{S} 1-\mathrm{S} 5$ based on CMC fluid extracts were diluted with $5 \mathrm{~mL}$ methyl alcohol p. a. (Reagent 1 of Analytik Jena procedure). From each syrup stock solution, were taken $5 \mu \mathrm{L}$, respectively $10 \mu \mathrm{L}$ working volume, according with Antioxidative Capacity in Lipid-soluble substances (ACL) procedure of Analytik Jena AG.

The total antioxidative capacity of the samples were quantified by comparison with the standard substance Trolox (6-hydroxy-2,5,7,8-tetramethylchroman-2-carboxylic acid) vitamin $\mathrm{E}$ derivative and is given in Trolox equivalent antioxidant activity (TEAC). Due to the difficulties in measuring individual antioxidant components of a complex vegetal mixture, Trolox equivalency (nmol/sample) is used as a benchmark for the antioxidant capacity of such a mixture. Calibration curve of Trolox standard is presented in Fig. 2. 


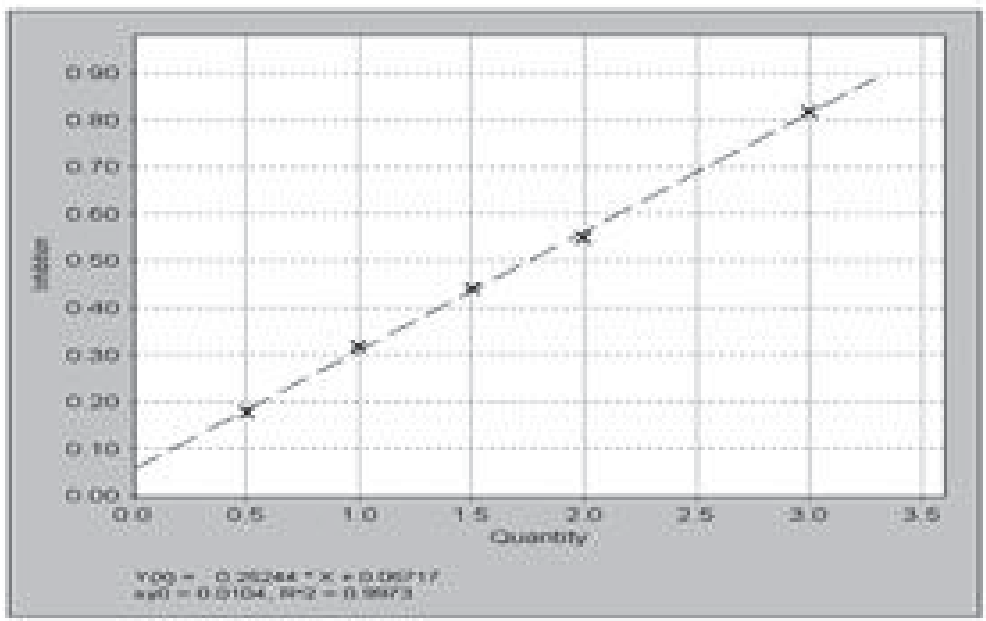

Fig. 2. Trolox standard calibration curve

\section{Results And Discussions}

The values of the determined parameters did not significantly modified, proving a good compatibility between the selected formula and CMC fluid extracts (Table VI).

HPLC assay results syrups S1 - S5 based on CMC fluid extracts are presented in figures 3 - 7 and polyphenolic compounds (PC) quantification is presented in Table VII.

Table VI. CMC fluid extracts quality control results

\begin{tabular}{|c|c|c|c|}
\hline Fluid extract type & $\mathrm{pH}$ & Relative density & Folin Ciocalteu assay, $\mathrm{mg} / 100 \mathrm{~g}$ vegetal product \\
\hline $\mathrm{C}$ & $4.65-5.0$ & $0.9423-1.058$ & 671.23 \\
\hline $\mathrm{M}$ & $5.24-5.51$ & $1.011-1.0253$ & 560.68 \\
\hline $\mathrm{C}$ & $5.35-5.69$ & $1.0023-1.0321$ & 384.70 \\
\hline
\end{tabular}

Table VII. Physical-chemical results for syrups based on CMC fluid extracts

\begin{tabular}{|c|c|c|}
\hline Parameter & Syrups (S1 - S4) & Syrup S5 \\
\hline Appearance & $\begin{array}{c}\text { Clear liquid, viscous, brownish color, } \\
\text { sweet taste, characteristic smell }\end{array}$ & $\begin{array}{c}\text { Clear liquid, slightly viscous, brown color, } \\
\text { characteristic smell }\end{array}$ \\
\hline$p \mathrm{H}$ & $5.6-6.2$ & $5.5-6.00$ \\
\hline Relative density & $1.2443-1.259$ & 1.037 \\
\hline
\end{tabular}

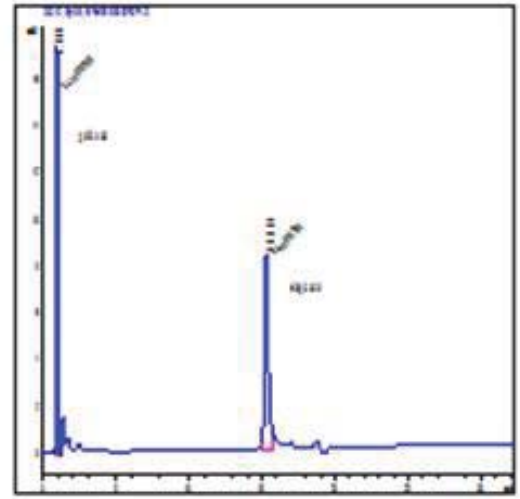

Fig. 3. Syrup 1 - HPLC analysis

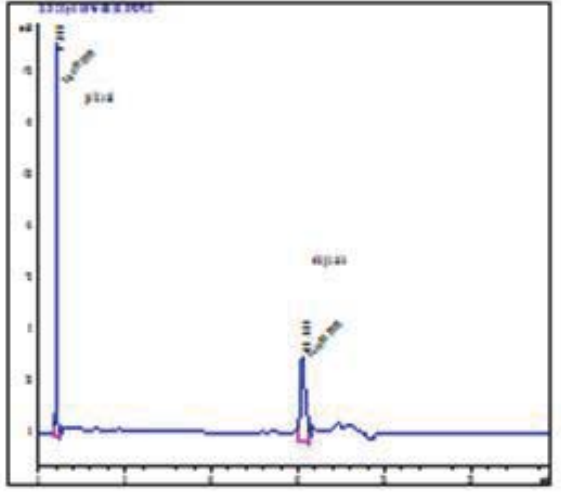

Fig. 4. Syrup 2 - HPLC analysis 


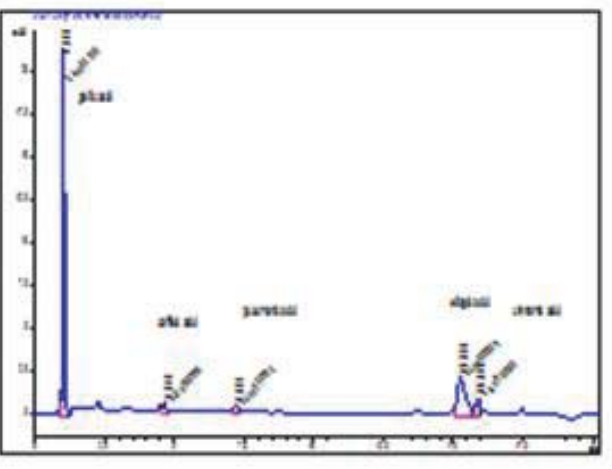

Fig. 5. Syrup 3 - HPLC analysis

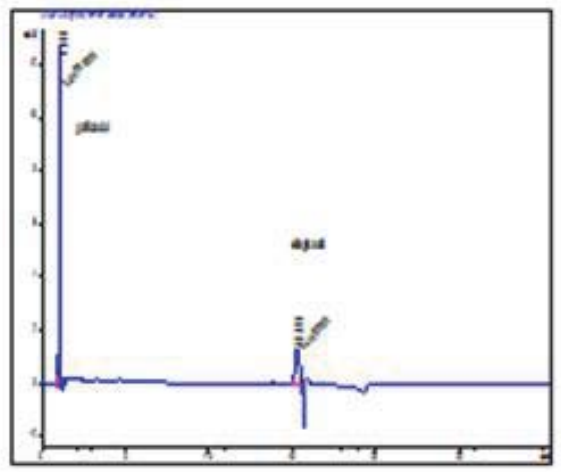

Fig. 6. Syrup 4 - HPLC analysis

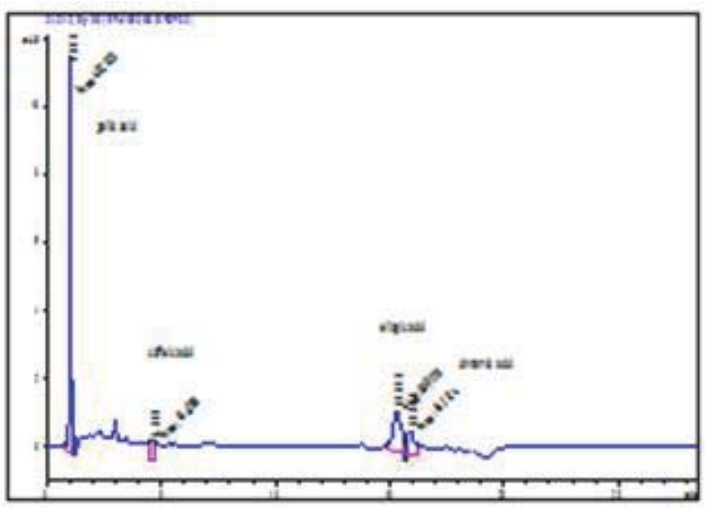

Fig. 7. Syrup 5 - HPLC analysis

Table VIII. Polyphenols compounds of syrups S1 - S5 by HPLC quantification [mg/ $100 \mathrm{~g}$ vegetal product] \pm SD

\begin{tabular}{|c|c|c|c|c|c|c|c|c|c|c|c|c|c|c|}
\hline $\begin{array}{l}\text { Syrup } \\
\text { type }\end{array}$ & \multicolumn{2}{|c|}{ Caffeic acid / SD } & \multicolumn{2}{|c|}{$\begin{array}{c}\mathrm{p} \text {-coumaric acid / } \\
\text { SD }\end{array}$} & \multicolumn{2}{|c|}{$\begin{array}{c}\text { Cinnamic acid / } \\
\text { SD }\end{array}$} & \multicolumn{2}{|c|}{$\begin{array}{l}\text { 3-methyl gallic } \\
\text { acid / SD }\end{array}$} & \multicolumn{2}{|c|}{$\begin{array}{c}\text { chlorogenic acid } \\
\text { / SD }\end{array}$} & \multicolumn{2}{|c|}{ Gallic acid / SD } & \multicolumn{2}{|c|}{ Ellagic acid / SD } \\
\hline S1 & 0.0000 & 0.0000 & 0.0000 & 0.0000 & 0.0000 & 0.0000 & 0.0000 & 0.0000 & 0.0000 & 0.0000 & 51.4857 & 1.1850 & 177.9698 & 1.6066 \\
\hline S2 & 0.0000 & 0.0000 & 0.0000 & 0.0000 & 0.0000 & 0.0000 & 0.0000 & 0.0000 & 0.0000 & 0.0000 & 19.6796 & 1.2566 & 97.3875 & 1.5039 \\
\hline S3 & 0.1555 & 0.0040 & 0.2430 & 0.0023 & 4.5555 & 0.5388 & 0.0000 & 0.0000 & 0.0000 & 0.0000 & 23. 3022 & 1.6880 & 51.6166 & 1.1110 \\
\hline S4 & 0.0000 & 0.0000 & 0.0000 & 0.0000 & 2.7460 & 0.5916 & 0.0000 & 0.0000 & 0.0000 & 0.0000 & 12. 0663 & 1.6357 & 17.6518 & 1. 1035 \\
\hline S5 & 0.2691 & 0.0145 & 0.0000 & 0.0000 & 7.2961 & 0.2238 & 0.0000 & 0.0000 & 0.0000 & 0.0000 & 13.1290 & 1.6431 & 34.8489 & 0.1437 \\
\hline
\end{tabular}

The obtained results (Table VIII) emphasize the presence of the follows polyphenols compounds:

- caffeic acid present in S3 - S5

- $\quad$ p-coumaric acid present in S3

- cinammic acid present in S3 - S5

- gallic acid present in S1 - S5

- ellagic acid present in S1 - S5 quantified.

In all syrups, gallic acid and ellagic acids were present in high concentration; small amounts of other acids were

\subsection{Total antioxidative capacity results for syrups S1 - S5 based on CMC fluid extracts mixture}

The obtained results regarding the total antioxidative capacity of CMC fluid extracts separately and syrups S1- S5 based on CMC fluid extracts mixture (stock solutions), are presented in Table IX, as average of two registered values for each sample. 
Table IX. Total antioxidative capacity for CMC fluid extracts and syrups S1- S5 based on CMC mixture

\begin{tabular}{|c|c|c|c|c|}
\hline No. & Sample type & Working volume sample $(\mu \mathrm{L})$ & Inhibition Max. value & $\begin{array}{c}\text { Quantity (TEAC) (nmol equiv. } \\
\text { Trolox/ volume sample) }\end{array}$ \\
\hline 1 & cornelian cherry extract $(\mathrm{C})$ & 5 & 0.643 & 3.729 \\
\hline 2 & black mulberry extract $(\mathrm{M})$ & 5 & 0,506 & 2,732 \\
\hline 3 & bitter cherry extract $(\mathrm{C})$ & 5 & 0,629 & 3,415 \\
\hline 4 & Syrup 1 & 5 & 0,161 & 0,650 \\
\hline 5 & Syrup 1 & 10 & 0,430 & 3,270 \\
\hline 6 & Syrup 2 & 5 & 0,331 & 1,898 \\
\hline 7 & Syrup 2 & 10 & 0,435 & 3,372 \\
\hline 8 & Syrup 3 & 5 & 0,297 & 1,573 \\
\hline 9 & Syrup 3 & 10 & 0,489 & 4,628 \\
\hline 10 & Syrup 4 & 5 & 0,443 & 3,518 \\
\hline 11 & Syrup 4 & 10 & 0,547 & 6,501 \\
\hline 12 & Syrup 5 & 5 & 0,503 & 5,064 \\
\hline 13 & Syrup 5 & 10 & 0,504 & 5,823 \\
\hline
\end{tabular}

- at working volume sample $(5 \mu \mathrm{L})$ according to the procedure, it was observed a low TEAC for all the analyzed samples, with values between $0,650-5.064 \mathrm{nmol}$ equiv. Trolox / volume sample.

- the most decreased total antioxidative capacity for sample Syrup 1 (0,650 nmol equiv. Trolox / volume sample), was registered.

- at working solution volume $(10 \mu \mathrm{L})$ according to the procedure, it was observed a high TEAC for all the analyzed samples, between 3,270 - 6,501 nmol equiv. Trolox / volume sample.

- at working solution volumes 5 and $10 \mu \mathrm{L}$ according to the procedure total antioxidative capacity, for Syrup 5 , very close values were registered (5. $064 \mathrm{nmol}$ equiv. Trolox / $5 \mu \mathrm{L}$ volume sample and 5. $823 \mathrm{nmol}$ equiv. Trolox / $10 \mu \mathrm{L}$ volume sample).

- $\quad$ the most increased total antioxidative capacity for sample Syrup 4 (6,501 nmol equiv. Trolox / $10 \mu \mathrm{L}$ volume sample), was registered.

\section{Conclusions}

- the new phytopharmaceuticals type syrups based on CMC fluid extracts after obtaining, did not have quality parameters modifications during 30 days of observation;

- syrups based on CMC fluid extracts contain most of the important polyphenols compounds, especially gallic acid and ellagic acids present in all analyzed samples;

- the vegetal fluid extracts present a decreased antioxidant activity compared with the one of the new syrups at the same working volume;

- the increased total antioxidative capacity for Syrup 4 (6,501 nmol equiv. Trolox / $10 \mu \mathrm{L}$ volume sample) and Syrup 5 (5. $823 \mathrm{nmol}$ equiv. Trolox / $10 \mu \mathrm{L}$ volume sample) was registered;

- CMC fluids extracts used for obtaining Syrup 4 and Syrup 5 were extracted under maceration and refluxing with alcohol $70 \%$, mixed in 1: 2,5: 1 CMC ratio;

- for Syrup 5, a syrup based on sodium carboxymethylcellulose, the big value for total antioxidative capacity is correlated with a rich polyphenolic content (caffeic, cinammic, gallic and ellagic acids), in this case, nature of base used for syrups obtaining (sucrose, sodium carboxymethylcellulose) interfered with antioxidative capacity;

- the new obtained syrups in variants S4 and S5, could be used for their antioxidative potential as a possible new nutritional supplements in associated oxidative stress dysfunctions.

\section{References}

Kalra E. K. , Nutraceutical-definition and introduction, AAPS PharmSci, 5 (3), 2003, 27 - 28

Shahidi, F. , Weerasinghe, D. K. , Nutraceutical Beverages: Chemistry, Nutrition, and Health Effects, American Chemical Society, 2004 Shahidi, F. , Naczk, M. , Phenolics in Food and Nutraceuticals (2nd edition), 2003, CRC Press

Hardy, G. , Nutraceuticals and functional foods: introduction and meaning, Nutrition 16 (7-8), 2000, 688-9 
Pathak, Y. V. (editor, 2010), Handbook of Nutraceuticals, vol. 1, Ingredients, Formulations, and Applications, CRC Press

Pârvu, C. , Enciclopedia Plantelor, vol. I, Editura Tehnică, Bucureşti, 2005

*** Enciclopedia delle erbe. Riconoscimento e uso medicinale, alimentare, aromatico, cosmetico, Translation from italian language, Editura Litera, 2012

Cercasov, C. , Oprea, E. , Popa, C. V. , Fărcăşanu, I. C. , Compuşi naturali cu acţiune terapeutică, Editura Universităţii din Bucureşti, 2009

Kalyoncu, I. H. , Ersoy, N. , Yılmaz M. , Some physico-chemical properties and mineral contents of sweet cherry (Prunus avium L. ) type grown in Konya, African Journal of Biotechnology, Vol. 8 (12), pp. 2744-2749, 2009

Chaovanalikit A. , Wrolstad R. E. , Anthocyanin and Polyphenolic Composition of Fresh and Processed Cherries, Journal of Food Science, Vol. 69, Nr. 1, 2004, C 73 - C 83

Melicháčová, S. , Timoracká, M. , Bystrická, J., Vollmannová A. , Čéry J - Relation of total antiradical activity and total polyphenol content of sweet cherries (Prunus avium L. ) and tart cherries (Prunus cerasus L. ), Acta agriculturae Slovenica, 95 - 1, 2010,21 $-28$

Song W. , Wang H. J. , Bucheli P. , Zhang P. F. , Wei D. Z. , Lu Y. H. , Phytochemical Profiles of Different Mulberry (Morus sp. ) Species from China, J. Agric. Food Chem. , 2009, 57, 9133-9140

Almeida S. \& all, Medicinal Plants and Natural Compounds from the Genus Morus (Moraceae) with Hypoglycemic Activity: A Review, 2012, licensee InTech

Muhammad Iqbal, Khan Mir Khan, Muhammad Salim Jilani and Muhammad Munir Khan, Physico-chemical characteristics of mulberry fruits, J. Agric. Res. , 2010, 48 (2)

Otakar R. , Mlcek J., Kramarova D. , Jurikova T., Selected cultivars of cornelian cherry (Cornus mas L. ) as a new food source for human nutrition, African Journal of Biotechnology Vol. 9 (8), pp. 1205-1210, 22 February, 2010

Demir, F. , Kalyoncu, I. H. , Some nutritional, pomological and physical properties of cornelian cherry (Cornus mas L. ). Journal of Food Engineering, 2003, 60, 335-34

Agata Maria Pawlowska, Fabiano Camangi, Alessandra Braca, Quali-quantitative analysis of flavonoids of Cornus mas L. (Cornaceae) fruits, Food Chemistry, Vol. , 119 (3), Elsevier, 2010

Ersoy N. , Bagci Y. , Gok V. , Antioxidant properties of 12 cornelian cherry fruit types (Cornus mas L. ) selected from Turkey, Scientific Research and Essays Vol. 6 (1), pp. 98-102, 2011

Popovici, I. , Lupuleasa, D. , Tehnologie farmaceutică, vol. I, Ediţia a III-a, Editura Polirom, Bucureşti, 2011

Negreanu-Pîrjol T. , Negreanu-Pîrjol B. S. , Popescu A. , Bratu M. M. , Udrea M. , Buşuricu F. , Comparative Antioxidante Properties of some Romanian Foods Fruits Extracts, Journal of Environmental Protection and Ecology, vol. 15, no. 3 (2014), 1139 - 1148

Negreanu-Pîrjol B. Ş. , Negreanu-Pîrjol T. , Bratu M. , Popescu A. , Roncea F. , Mireşan H. , Jurja S. , Paraschiv G. M. , Antioxidative activity of indigen bitter cherry fruits extract corellated with polyfenols and minerals content", 14th International Multidisciplinary Scientific GeoConferences „Surveying Geology \& mining Ecology Management - SGEM 2014”, 17 - 26 June 2014, Albena, Bulgaria, Conference Proceedings, Volume I, Section Advances in Biotechnology, $239-244$

${ }^{* * *}$ Antioxidative capacity lipid-soluble substances procedure, Photochem, Analytik Jena AG, Germany, 2004

Bratu M. M. , Doroftei E. , Negreanu-Pîrjol T. , Hoştină C. , Porta S. , Determination of Antioxidant Activity and Toxicity of Sambucus nigra Fruit Extract Using Alternative Methods", Food Technology and Biotechnology, 50 (2), 2012, 177-182 